Egyptian

Orthodontic Journal

\title{
DENTO-SKELETAL EFFECTS OF TWIN BLOCK-HEADGEAR IN TREATMENT OF CLASS II MALOCCLUSION CASES
}

\author{
Yasser L Abdelnaby ${ }^{1}$, Essam A Nassar ${ }^{2}$ \\ ABSTRACT:
}

Objective: To evaluate dental and skeletal effects of Twin Block-Headgear combination in treatment of Class II malocclusion cases. Material and Methods: Twenty five female growing patients with skeletal Class II due to 6oth mandibular retrognathism and maxillary prognathism were selected. Fifteen patients were treated using Twin Block with high pull headgear (THB-HFG group) for nine months, while the other ten patients had no treatments (control group). For each patient, lateral cephalometric x-ray film was taken at the start and the end of active functional treatment period and then traced and analyzed. The collected data were subjected to $t$ test to assess the significant differences in the changes in measurements between the two groups. Results: The T'B-HG group showed a significant maxillary growth restriction and enfiancement of the mandibular growth. The upper and lower incisors were significantly retroclined and proclined respectively. The maxillary molars moved distally while the mandibular molars moved mesialy. The mandibular plane and palatal plane angles showed no significant changes. Conclusions: Twin Block-Headgear appliance could be used successfully in treatment of skeletal Class II malocclussion due to maxillary protrusion and mandibular retrusion without adverse changes in the mandibular plane angle.

Key Words: Class II; Functional appliances; Twin Block; Headgear

\footnotetext{
${ }^{1}$ Associate Professor, Department of Orthodontics, Faculty of Dentistry, Mansoura University.

${ }^{2}$ Lecturer, Department of Orthodontics, Faculty of Dentistry, Mansoura University.
} 
Egyptian

Orthodontic Journal

\section{INTRODUCTION}

Skeletal Class II malocclusions have different configurations. The patients could be manifested with mandibular deficiency, maxillary excess or combination of the two. Different treatment modalities are available for management of Class II including the use of functional appliances and headgears. ${ }^{1-6}$ Several types of functional appliances were developed. ${ }^{7-11}$ Among these appliances is the Twin Block which is considered one of the most commonly used functional appliances. ${ }^{12}$ It was developed by William J Clark and consisted of two separate upper and lower bite-blocks that interlock at 45 or 70 degrees angles. ${ }^{2,13}$ It was designed for full time wear to take the advantages of all functional forces applied to the dentition including forces of mastication., ${ }^{2,7,13}$ The separate blocks, less bulky appearance and more freely mandibular movements would increase its patient acceptance compared to other removable functional appliances. ${ }^{14}$ Studies on the effects of Twin Block revealed that it produces both skeletal and dental effects. Significant decrease in overjet and overbite, increase in mandibular length, retroclination and extrusion of upper incisors, distal movements of upper molars and proclination of lower incisors were found to be the effect of appliance. However, increase in vertical face height is considered as unfavorable treatment effect of Twin Block and limits its use in patients with mandibular retrognathia and increased vertical dimention. ${ }^{8-10,12-15}$

There is a great debate regarding the effect There is a great debate regarding the effect of the functional appliances on the maxillary growth. It might be impared ${ }^{1,16}$, redirected ${ }^{17}$, or not changed ${ }^{11,18}$. Headgears have been used in conjunction with the functional appliances to augment the orthopedic effect on the maxilla. ${ }^{19-22}$ Clark in 1988 reported that orthopedic traction to support the action of the Twin Block could be used in cases where there is maxillary excess, mandibular retrusion, and vertical growth discrepancies. ${ }^{2}$ However, literature regarding the effects of Twin Block-Headgear combination is lacking. Parkin et $\mathrm{al}^{20}$ evaluated the dental and skeletal effects of modified Twin Block appliance that 
incorporated high pull headgear and torquing spurs on the central incisors. Their results demonstrated that this combination effectively controlled the maxillary complex in both vertical and sagittal direction maximizing Class II skeletal correction. There was a significant retroclination of upper incisors despite the presence of torquing spurs. However, absence of control untreated group in their study did not exclude the growth influence.

The present study was conducted to evaluate dental and skeletal effects of Twin Block-Headgear appliance in treatment of Class II cases with maxillary protrusion and mandibular retrusion.

\section{MATERIAL AND METHODS}

Twenty five female patients were selected for this study according to the following criteria:

- Skeletal Class II $\left(\mathrm{ANB}>5^{\circ}\right)$ due to both mandibular retrognathism and maxillary prognathism.

- Not passed the peak of the pubertal growth spurt at the beginning of treatment.

- The patient's age was ranged from 8 to 11 years.

- No previous history of orthodontic treatment.

- No oral habits.

Twin Block (TB) in conjunction with high pull headgear (HG) was used for treatment of 15 patients for 9 months (TB-HG group). No treatment was performed in the remaining 10 patients (control group).

The design of the TB appliance is shown in Figure 1. The appliance had Adams clasps on maxillary first molars and mandibular first premolars in addition to ball clasps on the upper and lower labial segments. The bite blocks interlocked at 70 degrees. Bite registration was taken with the mandible protruded 6-7 $\mathrm{mm}$ and 5-6 $\mathrm{mm}$ vertical separation posteriorly. The maxillary part of the appliance incorporated activator tubes for the headgear at the 
premolar regions and midline expansion screw to compensate the forward positioning of the mandible that was turned 1 turn per week. The patients were instructed to wear the TB appliances 24 hours a day. Extra-oral orthopedic forces of approximately 400 grams per side were applied by the high pull headgear for an average of 14 hours per day.

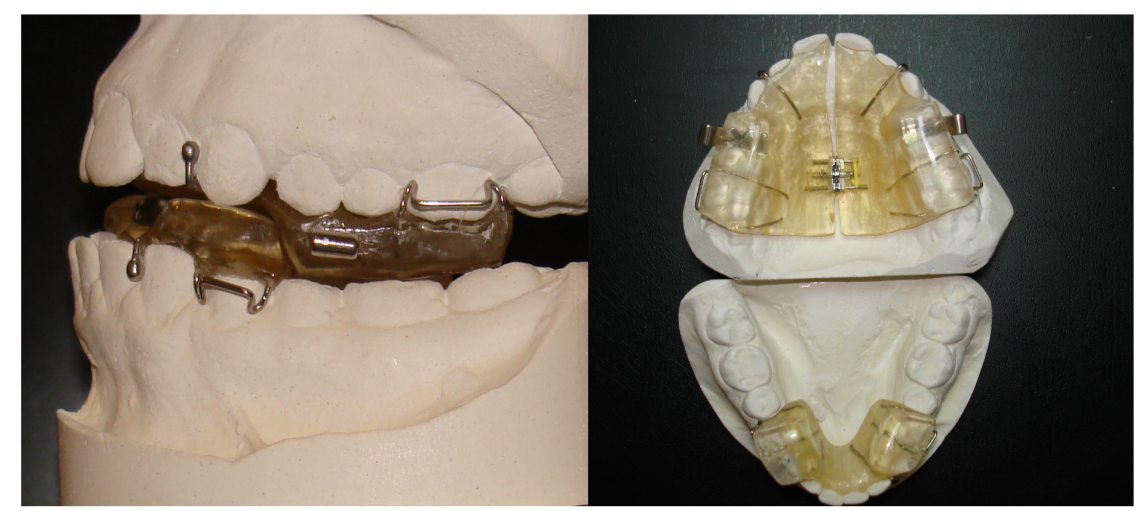

Figure 1: The Twin Block appliance.

Hand wrist x-ray film was taken for each patient to assess the skeletal maturation. The peak of pubertal growth spurt was defined as the epiphysis of the middle phalanx of the third finger cap its diaphysis. ${ }^{23}$ Lateral cephalometric x-ray films were taken at the start and the end of active functional treatment period ( 9 months) to evaluate the dental and skeletal changes. The lateral cephalograms were taken with one machine using same settings. All the films were obtained with teeth in centric occlusion and lips in relaxed position. ${ }^{24}$ The films were traced using 0.5 lead pencil on acetate paper. Cephalometric reference points were located, lines and planes were drawn and cepahometric analysis was done according to Pancherz's ${ }^{25}$ method (Figure 2) that depends on the occlusal plane (OL) and occlusal plane perpendicular (OLp). Cephalometric films were retraced and the method error was determined by using Dalhberg's formula which was less than $1 \mathrm{~mm}$ and 1 degree. 


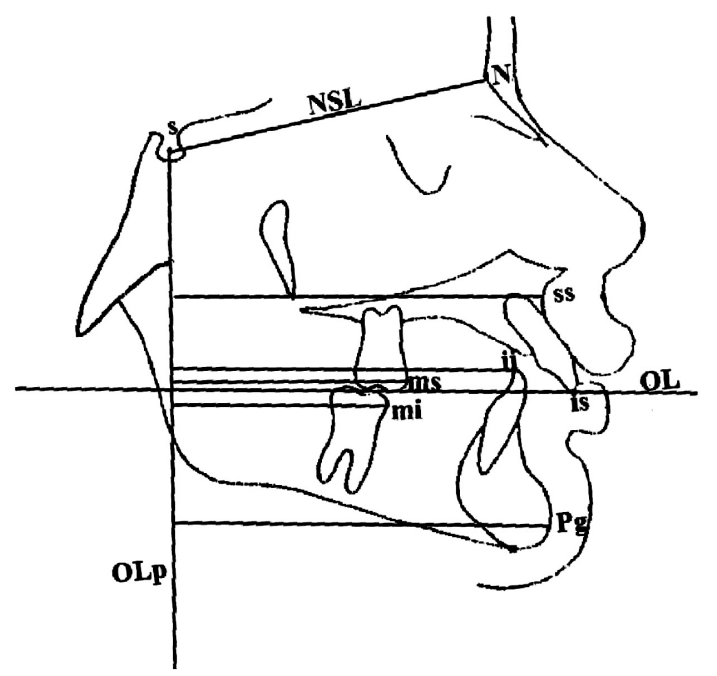

Figure 2: The reference points used in the cephalometric analysis.

\section{Statistical analysis:}

All measurements in both groups were calculated and analyzed using the SPSS statistical program (Chicago, IL). Descriptive statistics including means and standard deviations of the measurements and their changes before and after treatment in each group were obtained. Then, $t$ test was used to determine the significance differences in the changes of the measurements between the two groups. Significance for the statistical test was predetermined at $\mathrm{P}<0.05$.

\section{RESULTS}

The cephalometric measurements of the TB-HG and control groups before and after 9 months are presented in Table 1. Changes in the cephalometric measurements of both groups and the result of $t$ test are expressed in Table 2.

\section{The Anteroposterior Direction}

\section{Skeletal changes}

In general, the anteroposterior relationship of the maxillary and mandibular bases was improved in the TB-HG group in comparison to the 
control group. In the TB-HG group; the ANB angle was significantly decreased $(\mathrm{P}<0.0001)$. In addition, there were pronounced effects on the maxillary base as the SNA and ss/OLp were significantly decreased $(\mathrm{P}<0.0001)$. Furthermore, there was a noticeable influence on the mandibular base as the SNB and pg/OLp were significantly increased $(\mathrm{P}<0.0001$ and $\mathrm{P}=0.004$ respectively $)$.

Table 1: Means and standard deviations of the cephalometric measurements of TB-HG and control groups before and after 9 months.

\begin{tabular}{|l|c|c|c|c|}
\hline \multirow{2}{*}{ Measurements } & \multicolumn{2}{c|}{$\begin{array}{c}\text { TB-HG } \\
\text { (n=15) }\end{array}$} & \multicolumn{2}{c|}{$\begin{array}{c}\text { Control } \\
\text { (n=10) }\end{array}$} \\
\cline { 2 - 5 } & Before & After & Before & After \\
\cline { 2 - 5 } & Mean \pm SD & Mean \pm SD & Mean \pm SD & Mean \pm SD \\
\hline Anteroposterior Direction & & & & \\
\hline Skeletal changes & & & & \\
\hline SNA & $83.46 \pm 0.83$ & $82.4 \pm 0.98$ & $82.7 \pm 0.67$ & $83 \pm 0.81$ \\
\hline SNB & $75.26 \pm 1.48$ & $76.93 \pm 1.38$ & $75 \pm 0.94$ & $75.3 \pm 0.94$ \\
\hline ANB & $8.2 \pm 0.94$ & $5.4 \pm 0.82$ & $7.7 \pm 1.05$ & $7.8 \pm 1.13$ \\
\hline Maxillary base (ss/OLp) & $78.13 \pm 3.77$ & $76.73 \pm 3.65$ & $79.7 \pm 3.46$ & $80 \pm 3.71$ \\
\hline Mandibular base (pg/OLp) & $77.13 \pm 3.22$ & $79 \pm 3.54$ & $76.7 \pm 2.83$ & $77 \pm 2.74$ \\
\hline Dental changes & & & & \\
\hline Over jet (is/OLp-ii/OLp) & $10.8 \pm 1.93$ & $4.93 \pm 1.43$ & $10.1 \pm 0.79$ & $10.4 \pm 1.89$ \\
\hline Molar relation (ms/OLp-mi/OLp) & $1.7 \pm 3.87$ & $-4.13 \pm 2.29$ & $1.8 \pm 1.54$ & $2.0 \pm 1.49$ \\
\hline Maxillary incisor (is/OLp) & $91 \pm 6.81$ & $88.06 \pm 6.5$ & $90.6 \pm 6.46$ & $86.21 \pm 6.55$ \\
\hline Mandibular incisor (ii/OLp) & $77.9 \pm 5.32$ & $82 \pm 4.35$ & $80.5 \pm 4.74$ & $80.8 \pm 4.91$ \\
\hline Maxillary molar (ms/OLp) & $57.13 \pm 5.26$ & $53.53 \pm 4.06$ & $55.5 \pm 4.47$ & $55.9 \pm 4.5$ \\
\hline Mandibular molar (mi/OLp) & $51.26 \pm 5.07$ & $55 \pm 4.7$ & $50.6 \pm 4.81$ & $51 \pm 4.89$ \\
\hline Vertical Direction & & & & \\
\hline ML/NSL & $32.93 \pm 1.1$ & $32.83 \pm 1.53$ & $31.1 \pm 0.79$ & $31.4 \pm 2.27$ \\
\hline OL/NSL & $20.4 \pm 1.76$ & $21 \pm 1.77$ & $21.2 \pm 1.13$ & $21.5 \pm 0.84$ \\
\hline
\end{tabular}


Table 2: Means and standard deviations of changes in cephalometric measurements of TB-HG and control groups and the results of $t$ test.

\begin{tabular}{|l|c|c|c|c|}
\hline \multirow{2}{*}{ Measurements } & $\begin{array}{c}\text { TB-HG } \\
(\mathbf{n}=\mathbf{1 5})\end{array}$ & $\begin{array}{c}\text { Control } \\
(\mathbf{n = 1 0})\end{array}$ & \multicolumn{2}{|c|}{} \\
\cline { 2 - 5 } & Mean \pm SD & Mean \pm SD & t & P value \\
\hline Anteroposterior Direction & \multicolumn{2}{|l|}{} & & \\
\hline Skeletal Changes & & & & \\
\hline SNA & $-1.06 \pm 0.45$ & $0.3 \pm 0.48$ & 7.08 & $<0.0001^{*}$ \\
\hline SNB & $1.66 \pm 0.61$ & $0.4 \pm 0.51$ & 5.55 & $<0.0001^{*}$ \\
\hline ANB & $-2.8 \pm 0.56$ & $0.1 \pm 0.56$ & 12.58 & $<0.0001^{*}$ \\
\hline Maxillary base (ss/OLp) & $-1.4 \pm 1.18$ & $0.3 \pm 0.67$ & 4.56 & $0.0001^{*}$ \\
\hline Mandibular base (pg/OLp) & $1.86 \pm 1.68$ & $0.3 \pm 0.67$ & 3.23 & $0.004^{*}$ \\
\hline Dental Changes & & & & \\
\hline Over jet (is/OLp- ii/OLp) & $-5.86 \pm 1.8$ & $0.3 \pm 0.84$ & 12.5 & $<0.0001$ \\
\hline Molar relation (ms/OLp-mi/OLp) & $-5.93 \pm 2.71$ & $0.2 \pm 0.78$ & 8.25 & $<0.0001^{*}$ \\
\hline Maxillary incisor (is/OLp) & $-3 \pm 1.6$ & $0.3 \pm 0.67$ & 7.08 & $<0.0001^{*}$ \\
\hline Mandibular incisor (ii/OLp) & $4.06 \pm 1.38$ & $0.3 \pm 0.48$ & 9.67 & $<0.0001^{*}$ \\
\hline Maxillary molar (ms/OLp) & $-3.6 \pm 1.88$ & $0.4 \pm 0.51$ & 7.8 & $<0.0001^{*}$ \\
\hline Mandibular molar (mi/OLp) & $3.7 \pm 1.86$ & $0.4 \pm 0.51$ & 6.54 & $<0.0001^{*}$ \\
\hline Vertical Direction & & & & \\
\hline ML/NSL & $0+0.75$ & $0.3+0.67$ & 1.04 & 0.31 \\
\hline OL/NSL & $0.6+0.82$ & $0.3+0.94$ & 0.81 & 0.42 \\
\hline
\end{tabular}

${ }^{*} \mathrm{P}<0.05$

\section{Dental changes}

There was a significant difference in the changes of dental measurements between the two groups. In the TB-HG group, maxillary incisors were retroclined, while mandibular incisors were proclined. The is/OLp was significantly decreased $(\mathrm{P}<0.0001)$ while the ii/OLp was significantly increased $(\mathrm{P}<0.0001)$. In addition, the overjet was significantly decreased $(\mathrm{P}<0.0001)$. Also, the molars showed a significant movement. The maxillary molars moved in the distal direction while mandibular molars moved mesialy. The ms/OLp-mi/OLp and ms/OLp were significantly decreased $((\mathrm{P}<0.0001)$ while the mi/OLp was significantly increased $(\mathrm{P}<0.0001)$. 
Egyptian

Orthodontic Journal

\section{The Vertical Direction}

There were no significant differences between changes in the vertical measurements (ML/NSL and OL/NSL) of TB-HG group and control one $(\mathrm{P}=0.42$ and 0.24 respectively $)$.

\section{DISCUSSION}

The present study was conducted to evaluate the effects of TB-HG in treatment of Class II growing patients. To differentiate between the effect of the appliance and growth, control group was included in this study. The patients in the control group received treatment later on. Labial bow was not included in the maxillary part of the Twin Block in this study. Mills and $\mathrm{McCulloch}{ }^{26}$ demonstrated that, the absence of labial bow in the twin block appliance could reduce upper incisors retroclination due to absence of the labial bow in the Twin Block. In order to increase the orthopedic forces and improve the response to treatment, patients in TBHG group were instructed to wear the appliance 24 hours per day even during eating. ${ }^{2}$

The cephalometric analysis was done according to Pancherz ${ }^{25}$. This method was chosen since it allowed reference system close to the problem area and all registrations were performed to the same reference line OLp.

\section{The Anteroposterior Direction}

\section{Skeletal changes}

The results of the present study revealed that growth of the maxilla was significantly restricted in the TB-HG group in comparison to the control one. There were significant decrease in SNA angle and the length of Maxillary base (ss/OLP). Twin Block holds the mandible in a forward position resulting in reciprocal force acting distally on the maxilla. This intermittent force applied on almost full time bases. ${ }^{22}$ Also, headgear provides additional distal orthopedic force on the maxilla. The maxillary orthopedic effects of TB-HG were in agreement with those of other studies evaluating the combination of headgear and other functional appliances. $^{2,7,19,20,22,27-29}$ Meanwhile, these results were in disagreement with other studies that reported little orthopedic effects of the headgears. ${ }^{30,31}$ 
Egyptian

Orthodontic Journal

Regarding the mandible the TB-HG appliance had positive effects on the mandibular growth. There was significant increase in the mandibular base pg/OLp and SNB angle in comparison to the control group. This could be due to the use of Twin Block appliance altered the position of muscle balance and formation of tension zone distal to the condyle resulted in enhancement of the condylar growth. ${ }^{2}$ These findings matched those of other studies. ${ }^{8,15,19,20,22,32,33}$ However, these results were in contrast with others who found no excess mandibular growth was occurred with functional appliances. ${ }^{1,11}$

Consequently, the relationship between the maxillary and mandibular bases was improved in the TB-HG group. This was expressed by the significant decrease in the ANB angle. This finding was in harmony with the results of previous studies. $2,7,19,20,22,27-33$

\section{Dental changes}

The upper and lower incisors were retroclined and proclined respectively in the TB-HG group compared to the control one. The is/OLp was significantly decreased while the ii/OLp was significantly increased. Similarly, the maxillary molars were moved distally and the mandibular one moved mesialy. The ms/OLp and mi/OLp were significantly decreased and increased respectively in the TB-HG group. These findings always associated with the use of functional appliances as they provide Class II traction effect. ${ }^{22}$ Twin Block and headgear exert distal forces on the maxillary dentition. In addition, Twin Block holds the mandible in forward position and the muscles tend to retract it to its original position while the teeth are grasped by the appliance. These effects result also in posteroanterior forces on the mandibular dentition. These results matched those of other studies. $2,7,11,19,20,22,28-30,33$

\section{The Vertical Direction}

Regarding changes in the vertical direction; there were no significant differences in the mandibular plane and palatal plane angles (ML-NSL and OL-NSL) between the two groups. These results were in line with those of other studies. ${ }^{19,20,34,35}$ This could be attributed to the untrimmed bite-blocks of the Twin Block appliance prevented the eruption of the posterior teeth. Additionally, the high pull headgear could restrict the vertical maxillary growth as it produces a force directed close to the maxillary center of resistance. ${ }^{36}$ 


\section{CONCLUSIONS}

From this study the followings could be concluded:

- The TB-HG could be used successfully in treatment of skeletal Class II cases since it effectively restricts the maxillary growth and increase the manibular growth.

- The maxillary and mandibular incisors were retroclined and proclined respectively in the treatment group.

- The maxillary and mandibular molars were moved mesialy and distally respectively in the TB-HG group.

- No significant changes occurred in the vertical direction regarding the occlusal and mandibular plane in either group.

\section{REFERENCES}

1. Harvold EP, Vargervik K. Morphogenetic response to activator. Am J Orthod. 1971;60:478-490.

2. Clark WJ. The twin block technique. A functional orthopedic appliance system. Am J Orthod. 1988;93:1-18.

3. Almeida MR, Henriques JFC, Ursi W. Comparative study of Frankel (FR-2) and bionator appliances in the treatment of Class II malocclusions. Am J Orthod Dentofacial Orthop. 2002; 121:458-466.

4. Jacobs T, Sawaengkit P. National Institute of Dental and Craniofacial Research efficacy trials of bionator Class II treatment: a review. Angle Orthod. 2002: 72:571-575.

5. Brown P. A cephalometric evaluation of high-pull headgear and face-bow neck strap therapy. Am J Orthod. 1978;74:621-632.

6. Ghafari J, Shofer FS, Jacobsson-Hunt U, Markowitz DL, Laster LL. Headgear versus functional regulator in the early treatment of Class II, Division 1 malocclusion: A randamoized clinical trial. Am J Orthod Dentofacial Orthop. 1998;113:51-61.

7. Clark WJ. The Twin-block traction techniques. Eur J Orthod. 1982; 4:129-138. 
8. Toth LR, McNamara JA. Treatment effects produced by the twin-block appliance and FR-2 appliance of Frankle compared with untreated class II sample. Am J Orthod Dentofacial Orthop. 1999; 116:597-609.

9. Gill D S, Lee RT. Prospective clinical trial comparing the effects of conventional Twin Block and mini-block appliances: part 1. Hard tissue changes. Am J Orthod Dentofacial Orthop. 2005;127:465-472.

10. Lee RT, Kyi CS, Mack GJ. A controlled trial of the effects of the twin block and dynamax appliances on the hard and soft tissues. Eur J Orthod. 2007;29:272-282.

11. Wieslander L, Lagerstorm L. The effects of activator treatment on class II malocclusions. Am J Orthod. 1979; 75:20-26.

12. Chadwick SM, Banks P, Wright JL. The use of myofunctional appliances in the UK: a survey of British orthodontists. Dental Update. 1998;25:302-308.

13. Clark WJ. Twin block functional therapy. London: Mosby-Wolfe; 1995.

14. Floris-Mir C, Major PW. Cephalometric facial soft tissue changes with the twin block appliance in class II division 1 malocclusion patients.Angle Orthod. 2006;76:876-881.

15. Jena AK, Duggal R, Parkask H. Skeletal and dentoalveolar effects of twin block and bionator appliances in the treatment of class II malocclusion: A comparative study. Am J Orthod Dentofacial Orthop. 2006; 130:594-602.

16. Jacobsson SO. Cephalometric evaluation of treatment effect on class II division 1 malocclusions. Am J Orthod. 1967;53:446-457.

17. Woodside DG, Reed RT, Doueet JD, Thompson GW. Some effects of activator treatment on growth rate of the mandible and position of mid face. London: Crosby, Lockwood and Staples: 1975.p 459-480.

18. Clavert FJ. An assessment of Andresen therapy on Class II Division 1 malocclusion. Br J Orthod. 1982:9:149-153. 
19. Üçüncü N, Türk T, Carles C. Comparison of modified Teuscher and Van Beek Functional Appliance Therapies in High-Angle Cases. J Orofac Orthop/Fortschr Kieferothop. 2001; 3:224-237.

20. Parkin NA, McKeown HF, Sandler PJ. Comparison of 2 modifications of the twin-block appliance in matched Class II samples. Am J Orthod Dentofacial Orthop. 2001; 119:572-577.

21. de Almedia-Pedrin RR, de Almedia MR, de Almedia RR, Pinzan R, Ferreira FPC. Treatment effects of headgear biteplane and bionator appliances. Am J Orthod Dentofacial Orthop. 2007; 132:191-198.

22. Illing HM, Morris DO, Lee RT. A prospective evaluation of Bass, Bionator and Twin Block appliances. Part I-the hard tissue. Eur J Orthod. 1998;20:501-516.

23. Hägg U, Taranger J. Maturation indicators and the pubertal growth spurt. Am J Orthod. 1982;82:299-309.

24. Hillesund E, Fjeld D, Zachrisson B U. Reliability of soft-tissue profile in cephalometrics. Am J Orthod. 1978;25:225-230.

25. Pancherz $H$. The mechanism of class II correction in Herbst appliance treatment A cephalometric investigation. Am J Orthod. 1982;82:104-113.

26. Mills CM, McCulloch KJ. Treatment effects of twin block appliance: a cephalometric study. Am J Orthod Dentofacial Orthop. 1998; 114:15-24.

27. Martins RP, Da Rosa Martins JC, Martins LP, Buschang PH. Skeletal and dental components of Class II correction with the bionator and removable headgear splint appliances. Am J Orthod Dentofacial Orthop. 2008; 134:732-741.

28. Seckin O, Surucu R. Treatment of Class II, division 1 cases with a maxillary traction splint. Quintessence Int. 1990;21:209-215.

29. Uner O, Yucel-Eroglu E. Effects of a modified maxillary orthopaedic splint: a cephalometric evaluation. Eur J Orthod. 1996;18:269-286.

30. Schiavon Gandini MR, Gandini LG Jr, Da Rosa Martins JC, Del Santo M Jr. Effects of cervical headgear and edgewise appliances on growing patients. Am J Orthod Dentofacial Orthop. 2001; 119:531-539. 
31. Keeling SD, Wheeler TT, King GJ, Garvan CW, Cohen DA, Cabassa S, et al. Anteroposterior skeletal and dental changes after early Class II treatment with Bionator and headgear. Am J Orthod Dentofacial Orthop. 1998; 113:40-50.

32. Mills CM, McCulloch KJ. Posttreatment changes after successful correction of Class II malocclusions with the Twin-block appliance. Am J Orthod Dentofacial Orthop. 2000; 118:24-33.

33. Trnouth MJ. Cephalometric evaluation of the Twin-block appliance in the treatment of Class II Division 1 malocclusion with matched normative growth data. Am J Orthod Dentofacial Orthop. 2000; 117:54-59.

34. Hansson C, Sköld P, Linder-Aronson S. Treatment of adolescents with Hansaplate/Headgear. J Orofac Orthop/Fortschr Kieferothop. 1997; 58:16-29.

35. Levin RI. Activator headgear therapy. J Orthod. 1985;87:91-109.

36. Proffit WR, Fields HW Jr, Sarver DM. Contemporary Orthodontics. $4^{\text {th }}$ Ed, Mosby, Inc., Elsevier Inc. 2007. 